\title{
Undernournishment and
} Yersinia enterocolitica enterocolitis alter intestinal contractility in the rabbit: Role of smooth muscle contractile protein content

\author{
Beth C Chin PhD, Daimen TM Tan BSc, R Brent Scott MDCM FRCPC
}

BC Chin, DTM Tan, RB Scott. Undernournishment and Yersinia enterocolitica enterocolitis alter intestinal contractility in the rabbit: Role of smooth muscle contractile protein content. Can J Gastroenterol 1998;12(4):319-324. Previous studies have demonstrated that the longitudinal smooth muscle of rabbits infected with Yersinia enterocolitica and undernourished because of reduced food intake exhibit a significantly reduced ability to develop tension in response to carbachol compared with pair-fed animals, which are uninfected but equivalently undernourished. To determine whether the alteration in smooth muscle contractility results from changes in cell number (hypo- or hyperplasia), or in contractile protein content or isoform distribution, New Zealand White rabbits (600 to $1000 \mathrm{~g}$ ) were randomly assigned to one of three treatment groups: infected, pair-fed or control. Tissue contractility was measured, morphometric studies were performed and immunoassays were developed for the measurement of total actin, gamma-enteric and alpha-vascular isoactins, and myosin heavy chain. Consistent with what was found in previous reports, the contractility of longitudinal smooth muscle in response to carbachol was found to increase in pair-fed animals and to decrease in $Y$ enterocolitica-infected animals. There was no significant change in the proportional thickness of the ileal longitudinal smooth muscle coat, and the number of cross-sectioned longitudinal smooth muscle cells $/ \mathrm{mm}^{2}$ was not significantly different in infected, pair-fed or control tissues. Immunoassay indicated that the proportion of each specific contractile protein, relative to total protein content in the muscularis propria, was unaf- fected by Y enterocolitica infection or by pair-feeding. Thus, the alterations in intestinal longitudinal smooth muscle function observed after $Y$ enterocolitica infection were concluded not to be associated with tissue hypo- or hyperplasia, or changes in the total content or isoform distribution of contractile proteins in the muscularis propria.

Key Words: Contractile proteins; Contractility; Immunoassay; Longitudinal intestinal smooth muscle; Morphology; Yersinia enterocolitica

\section{La malnutrition et l'entérocolite à Yersinia enterocolitica altèrent la contractilité intestinale chez le lapin : rôle du contenu en protéines contractiles du muscle lisse}

RÉSUMÉ: Des études ont déjà démontré que le muscle lisse longitudinal des lapins infectés à Yersinia enterocolitica et dénutris en raison d'un apport alimentaire moindre, manifestent une aptitude significativement réduite à développer une tension en réponse au carbachol, en comparaison avec des animaux-témoins nourris ensemble qui ne sont pas infectés, mais aussi dénutris. Afin de déterminer si l'altération de la contractilité du muscle lisse résulte d'un changement du nombre des cellules (hypo- et hyperplasie), de leur contenu en protéines contractiles ou de la distribution de leurs isoformes, des lapins blancs New Zeland (de 600 à 1000 g) ont été assignés aléatoirement à l'un des trois groupes suivants : infectés, animaux-témoins nourris ensemble ou témoins. On a mesuré la contractilité tissulaire, on a effectué les analyses morphométriques et on a utilisé des immunodosages

voir page suivante

Gastrointestinal Research Group and the Department of Pediatrics, University of Calgary, Calgary, Alberta

Correspondence and reprints: Dr R Brent Scott, Department of Pediatrics, Faculty of Medicine, Health Sciences Centre, University of Calgary, 3330 Hospital Drive NW, Calgary, Alberta T2N 4N1. Telephone 403-220-4556, fax 403-283-3028, e-mail scott@acs.ucalgary.ca 
pour calculer les taux d'actine totale, d'isoactines gamma-entériques et alpha-vasculaires et les chaînes lourdes de myosine. À l'instar des rapports précédents, en réponse au carbachol, la contractilité des muscles lisses longitudinaux a augmenté chez les animaux-témoins nourris et a diminué chez les animaux infectés à $Y$. enterocolitica. On n'a noté aucun changement significatif quant à l'épaisseur proportionnelle de la couche musculaire lisse longitudinale de l'iléon et le nombre de cellules du muscle lisse longitudinal transversal $/ \mathrm{mm}^{2}$ n'a pas été significativement différent dans les tissus des animaux infectés, des animaux-témoins nourris ensemble ou des témoins. L'immunodosage a indiqué que la proportion de chaque protéine contractile spécifique par rapport au contenu protéique total dans la muscularis propria n'était aucunement affectée par l'infection à Y. enterocolitica ni par le statut d'animal-témoin nourri ensemble. On en a conclu que les altérations de la fonction du muscle lisse longitudinal intestinal observées après l'infection à $\mathrm{t}$ is well established in both humans (1-4) and animals $(5,6)$ that Yersinia enterocolitica infection is an important cause of bacterial enterocolitis. Y enterocolitica-infected patients present with diarrhea and abdominal cramping, while the clinical illness (Yersinia infection) may manifest as either an acute gastroenteritis or a chronic relapsing ileocolitis similar to Crohn's disease of the terminal ileum. The rabbit model of Y enterocolitica enteritis is characterized by diarrhea, reduced food intake, weight gain and an increased rate of aboral transit $(5,6)$. In vitro studies have shown that longitudinal smooth muscle from the ileum of Y enterocolitica-infected rabbits generates significantly less stress in response to the muscarinic agonist carbachol, with no accompanying change in the muscles' passive contractile properties (7). In contrast, the responses of tissues from the pair-fed (undernourished, but not $Y$ enterocolitica-infected) control group to both carbachol and potassium chloride stimulation were significantly enhanced (7). The response was reproduced with potassium chloride depolarization and, therefore, likely resulted from a postreceptor change in smooth muscle function (7). Tissue hypo- or hyperplasia (changes in cell number) and changes in the content and isoform distribution of the contractile proteins are potential mechanisms for the postreceptor change.

Changes in the contractile protein mRNA or isoform content found in gastrointestinal tract tissue have been shown to occur with dysfunction or disease and may be associated with changes in tissue contractility. In a rat model of the adaptation of the residual functional bowel to a $70 \%$ intestinal bypass, there was an association between the thickening of the muscularis propria and the specific elevation of alpha-smooth muscle actin mRNA (8). In prairie dogs fed a high cholesterol diet for eight days, a proportionate increase in gamma-isoactin protein and a concurrent decrease in alpha-isoactin protein (9) were speculated to be functionally associated with a previously documented reduction in gallbladder contractility $(10,11)$. In a rat model of Trichinella spiralis infection the following were noted: an association between hypertrophy (change in the size of cells) and hyperplasia of the muscularis propria (12); an increase in the contractility of the longitudinal smooth muscle (13); an increase in the expression of the mRNAs that encode alpha-smooth muscle actin; and an increase in actin protein content (14). Similar findings have been reported in other organ systems. In models of load-induced cardiac hypertrophy, actin and myosin underwent changes in isoform expression (15-18). The alterations were independently regulated (18-20), and the altered expression of isoforms resulted in altered longitudinal smooth muscle contractility $(21-22)$.

Thus, the aim of the present study was to determine whether altered longitudinal smooth muscle contractility in pair-fed or $Y$ enterocolitica-infected groups resulted from tissue hypo- or hyperplasia, or from alterations in contractile protein content or isoform distribution in the muscularis propria.

\section{ANIMALS AND METHODS}

Experimental design: New Zealand White rabbits with initial weights of 600 to $1000 \mathrm{~g}$ were purchased from Vandermeer, Sherwood Park, Alberta and housed individually in stainless steel, mesh-bottom cages. A 12 h light/dark cycle was maintained in a temperature- and humiditycontrolled environment. All experimental procedures were approved by the University of Calgary Animal Care Committee.

Rabbits were randomly assigned to one of three treatment groups. In the infected group $(n=16)$, rabbits were inoculated orogastrically with $10^{10} \mathrm{Y}$ enterocolitica delivered in $10 \mathrm{~mL}$ of $10 \%$ sodium bicarbonate. Pair-fed rabbits $(n=17)$ were inoculated with $10 \mathrm{~mL}$ of $10 \%$ bicarbonate buffer alone. To mimic the reduced weight gain consistently observed following $Y$ enterocolitica infection, the experiment for the pair-fed group started one day after the infected group so that the pair-fed group's daily food allotment could be restricted to the average food intake of infected rabbits from the previous day. A second, untreated control group $(n=11)$ was also inoculated with $10 \mathrm{~mL}$ of $10 \%$ bicarbonate buffer alone but were allowed to feed ad libitum throughout the study. Daily food intake and body weight were monitored for each treatment group. In addition, daily rectal swabs were performed and cultured on salmonella-shigella agar plates to test for the presence of Y enterocolitica.

The alterations in longitudinal smooth muscle contractility associated with Y enterocolitica enteritis and undernourisment are maximal in the terminal ileum at day $6(7)$. Thus, on day 6 postinoculation, rabbits were sacrificed with an overdose of sodium pentobarbital administered by intracardiac injection. A $10 \mathrm{~cm}$ segment of distal ileum (beginning $10 \mathrm{~cm}$ proximal to the ileocecal valve) was quickly removed and placed in oxygenated ice-cold Krebs buffer, the composition of which was sodium chloride $120.3 \mathrm{mM}$, potassium chloride $5.9 \mathrm{mM}$, calcium chloride $2.5 \mathrm{mM}$, magnesium chloride $1.2 \mathrm{mM}$, sodium bicarbonate $15.4 \mathrm{mM}$, sodium bisphosphate $1.2 \mathrm{mM}$ and glucose $11.5 \mathrm{mM}$. Intestinal segments were opened along the site 
of mesenteric attachment, pinned out mucosal side down in wax dishes containing oxygenated ice-cold Krebs buffer and divided into three equal portions. Longitudinal tissue strips $0.5 \times 2.0 \mathrm{~cm}$ were obtained from the first portion for the contractility experiments. Tissue for histologic studies was obtained from the second portion, and longitudinal smooth muscle for the contractile protein content assay was obtained from the third.

Contractility studies: To show that previously reported contractility changes (7) could be reproduced in the rabbits used in the present study, full thickness longitudinal muscle strips were taken from the distal ileum of $Y$ enterocolitica-infected and pair-fed animals six days postinoculation, and were suspended between the base of a $25 \mathrm{~mL}$ organ bath and an isometric force transducer. Tissues were bathed in Krebs buffer. The temperature was maintained at $37^{\circ} \mathrm{C}$, and the bath was continuously bubbled with $95 \%$ oxygen and $5 \%$ carbon dioxide. In addition, $10^{-6} \mathrm{M}$ tetrodotoxin was present throughout all experiments. Mechanical activity of the longitudinal muscle was detected by isometric force transducers, enhanced by a transducer amplifier, relayed to a bioelectric amplifier and recorded on an eight-channel chart recorder (7).

Following a $30 \mathrm{~min}$ equilibration period, tissues were stretched to their optimal length $\left(\mathrm{L}_{\mathrm{o}}\right)$, ie, the muscle length at which peak active tension was developed in response to $10^{-5} \mathrm{M}$ carbachol. Preliminary experiments determined that for all treatment groups $\mathrm{L}_{\mathrm{o}}$ was $125 \%$ of initial tissue length. After being stretched, tissues were left to equilibrate for a further 30 mins. The active tension developed in response to $10^{-5} \mathrm{M}$ carbachol was then measured. At the end of each experiment, ileal tissue strips were removed from the tissue baths, scraped free of mucosa with glass slides and lightly blotted. Tissue dry weights were recorded.

Active contractile responses were normalized to tissue cross-sectional area as previously described (7). In addition, histological assessment yielded the fraction of thickness of the wet muscle strip attributable to the longitudinal muscle alone. Using these data, all calculations were corrected so that tension was normalized to the crosssectional area of the longitudinal muscle alone. Tension was expressed in units of stress, $\mathrm{mN} / \mathrm{mm}^{2}$.

Morphometry: Longitudinal smooth muscle cell hyper-or hypotrophy can occur in two dimensions - along the long axis and circumferentially. Hyper-or hypotrophy along the longitudinal axis must be associated with a change in either the circumference or the thickness of the longitudinal smooth muscle coat. The number of cross-sectioned longitudinal smooth muscle cells per unit area was used to assess changes in the circumferential plane.

To perform tissue morphometry, the allocated segment of ileum was removed from the iced Krebs solution and opened longitudinally along the mesenteric attachment. Next, the external circumference was measured by laying a $1.8 \mathrm{~g}$ plastic ruler across the width of the opened gut, and the segment was stapled to cardboard and placed in forma- lin for fixation. Formalin-fixed tissues were embedded in paraffin, thick-sectioned ( 3 to $4 \mu \mathrm{m}$ ), and stained with hematoxylin and eosin. Cross-sections of the longitudinal smooth muscle layer of each tissue section and a hemocytometer grid were visualized under oil immersion (x1000 power) with a microscope (Ernst Leitz $\mathrm{GmbH}$, Wetzlar, Germany). The thickness of the longitudinal muscle layer was measured with an ocular micrometer and by means of standard image-splitting micrometry, and was expressed as a proportion of the total thickness of the muscularis propria.

Photomicrographs were taken of each tissue section. The number of cross-sectioned longitudinal smooth muscle cells per unit area (including all whole cells within the grid and all partial cells adjacent to the bottom and left margin of the grid) was then determined by comparing the photographs of the tissue with those of the grid. Cell counts were made independently by two observers without knowledge of the origin of the specimen. Because the two separate counts were highly correlated $(r=0.97)$ and not significantly different, the mean of the two counts is reported.

Contractile protein immunoassay: With the aid of a dissecting microscope and Dumont \#5 fine forceps (Dumont, Montignez, Switzerland), the longitudinal muscle layer was gently peeled away from the remaining ileal tissue. Following measurement of wet weights, tissues were stored at $-70^{\circ} \mathrm{C}$.

At a later date, individual longitudinal muscle tissues were first minced and then homogenized by hand in a solution of $0.5 \mathrm{M}$ Tris- $\mathrm{Cl} \mathrm{pH} 6.8,0.5 \mathrm{M}$ dithiothreitol, $5 \%$ sodium dodecyl sulphate and $10 \%$ glycerol, at a concentration of $100 \mathrm{mg}$ wet weight tissue/mL buffer. All samples were stored at $-70^{\circ} \mathrm{C}$ for later assay.

Total protein was determined in the following manner. First, $650 \mu \mathrm{L}$ of ice-cold $10 \%$ trichloroacetic acid (TCA) was added to $50 \mu \mathrm{L}$ of original sample and left on ice for 30 mins. Samples were then spun in a microcentrifuge at $13,000 \mathrm{~g}$ for $15 \mathrm{mins}$. Next, the supernatant was removed, and the protein pellet washed with ice cold $70 \%$ ethanol. Following a spin at $13,000 \mathrm{~g}$ for 3 mins, the supernatant was again removed, and the pellets left to air dry for 60 mins at room temperature. Pellets were resuspended in 50 $\mu \mathrm{L}$ of $1 \mathrm{~N}$ sodium hydroxide. Because this was the original sample volume no dilution was made during the TCA precipitation procedure. Total protein was then determined using a detergent compatible protein assay kit (Bio-Rad). Bovine gamma globulin was TCA precipitated in the same manner as the study samples, and concentrations of bovine gamma globlin were used to generate a standard curve for the total protein assay.

Immunoassays measuring the amounts of myosin heavy chain, alpha-enteric isoactin and alpha-vascular isoactin were performed on the original samples. Diluted appropriately in carbonate buffer (sodium carbonate $15 \mathrm{mM}$, sodium bicarbonate $35 \mathrm{mM}$; $\mathrm{pH} 9.6$ ), $50 \mu \mathrm{L}$ of sample was delivered to each of three wells in a 96-well plate. To indi- 


\section{GIZZARD ACTIN}

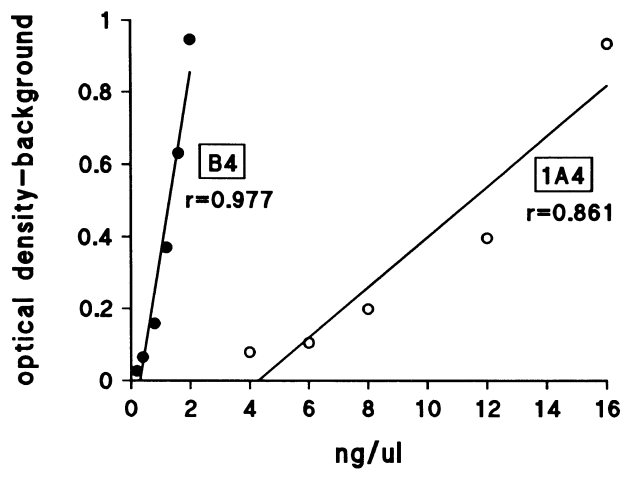

ABDOMINAL AORTA

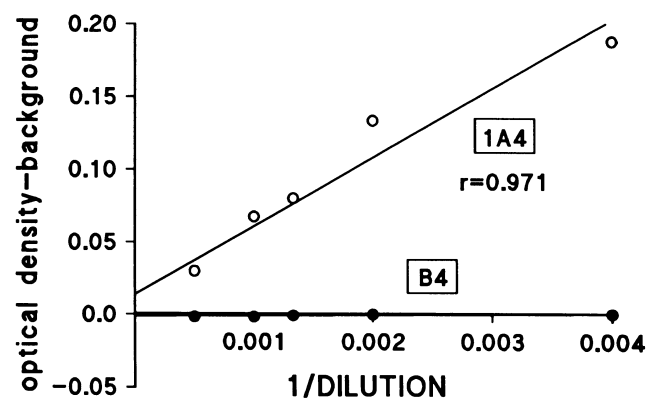

Figure 1) Top Representative standard curve of chicken gizzard actin. Commercially available chicken gizzard actin was serially diluted and assayed using a monoclonal antibody (B4) directed against gamma- enteric isoactin (solid circles). Regression analyisis indicated a linear relationship with an $r$ value of 0.98 . A standard curve was also generated by using a monoclonal antibody directed against alpha-vascular isoactin (1A4), although its sensitivity for gizzard actin was much less than that of the gamma-enteric antibody, B4. Bottom Representative standard curve of rat abdominal aorta, serially diluted and assayed by using a monoclonal antibody directed against alpha-vascular isoactin (1A4). Regression analysis indicated a linear relationship with an $r$ value of 0.97 (open circles). For comparison, the serially diluted sample was also assayed using antibody B4. For this monoclonal antibody directed against gamma-enteric isoactin, optical density never exceeded the level of background at any concentration tested (solid circles)

cate background protein levels, homogenization buffer, diluted in the same manner as the treatment samples, was added to six to 12 wells. Plates were then incubated for 48 to $72 \mathrm{~h}$ at $4^{\circ} \mathrm{C}$ to allow the samples and buffer to coat the wells. Samples and buffer were removed from the wells with a plate washer, and the wells were washed six times with phosphate-buffered solution plus $0.05 \%$ Tween 20 solution. The washing procedure was repeated after each incubation throughout the immunoassay. Nonspecific binding sites were blocked with $4 \%$ bovine serum albumin in phosphate-buffered saline containing $0.05 \%$ Tween 20 (30 mins, room temperature). Each sample was then incubated with a single primary monoclonal antibody $(1.5 \mathrm{~h}$, room temperature) followed by a secondary immunoglobulin $\mathrm{G}$ antibody peroxidase conjugate ( $1 \mathrm{~h}$, room tempera- ture). Colour development was achieved by adding $50 \mu \mathrm{L}$ of freshly prepared o-phenylenediamine solution (citric acid $0.1 \mathrm{M}$, sodium monophosphate $0.1 \mathrm{M}$, o-phenylenediamine $15 \mathrm{mg}, 30 \%$ hydrogen peroxide $15 \mathrm{mg}$ ) to each well. After 15 to 20 mins the peroxidase reaction was terminated by adding $25 \mu \mathrm{L}$ of $2.5 \mathrm{M}$ sulphuric acid to each well. Optical density was measured at $490 \lambda$. Within a given assay, all samples were measured at the same dilution and in triplicate. The average background optical density for each plate ( 0.044 to 0.056 optical density units) was subtracted from all sample data.

Commercially available chicken gizzard actin immunoassay results were used to generate the standard curve for the gamma-enteric isoactin assay, thus enabling quantification of gamma-enteric isoactin. The data for alpha-vascular isoactin and myosin were expressed as their absolute optical densities. In all cases the level of contractile protein present in a given sample was expressed relative to its total protein content (Figure 1).

Statistical analysis: Data were reported as mean \pm SE and were analyzed using ANOVA with a Tukey test for posthoc comparisons. $\mathrm{P}<0.05$ was considered significant.

Materials: Monoclonal antibodies to alpha-enteric and alpha-vascular isoactins were generously donated by Dr J Lessard (University of Cincinnati, Cincinnati, Ohio), but can be purchased commercially from ICN Biomedicals (California). Chicken gizzard actin, o-phenylenediamine, EGTA, tetrodotoxin, verapamil, monoclonal antibody to smooth muscle myosin heavy chain and antimouse immunoglobulin $G$ peroxidase conjugate were purchased from Sigma Chemical Co (Missouri). The detergent compatible protein assay kit was purchased from Bio-Rad. Immunoassay plates from VWR Canlab were read using a kinetic microplate reader purchased from Molecular Devices (California).

The isometric force transducers (Model 50-7905) and transducer amplifiers (Model 50-7970) were purchased from Harvard Apparatus Ltd (Kent, United Kingdom). Bioelectric amplifiers (Model 8811A) and an eight channel chart recorder (Model 7858A) were obtained from Hewlett Packard.

The statistical software package Systat was purchased from Systat (Illinois).

\section{RESULTS}

Clinical response, body weight and food intake: Only the group of rabbits infected with $\mathrm{Y}$ enterocolitica exhibited diarrhea and were positive for $\mathrm{Y}$ enterocolitica on culture of rectal swabs. Body weight was similar in the three groups at study onset (untreated controls $1019 \pm 36 \mathrm{~g}$, pair-fed group $985 \pm 29 \mathrm{~g}$, infected group $921 \pm 38 \mathrm{~g}$; not significant). However, the infected group's daily food intake decreased as early as day 2 postinfection and remained significantly reduced for the duration of the study (untreated controls $87.5 \pm 10 \mathrm{~g} /$ day; pair-fed animals [restricted to the mean daily food intake of the infected animals] 44.4 $\pm 5.6 \mathrm{~g} / \mathrm{day}, \mathrm{P}<0.05)$. As a consequence, by 
day 6 of the study, body weight in the infected $(954 \pm 26 \mathrm{~g})$ and pair-fed control groups $(1006 \pm 39 \mathrm{~g})$ increased by only $5 \%$ and $2 \%$, respectively (not significant), while the untreated, ad libitum-fed group, had a body weight of $1296 \pm 33 \mathrm{~g}$ on day 6 , which represented a significant $(\mathrm{P}<0.025) 28 \%$ increase in body weight over the study interval.

Contractility: In the presence of normal Krebs buffer, ileal tissues from pair-fed rabbits developed significantly more stress in response to $10^{-5} \mathrm{M}$ carbachol than tissues from either control or infected rabbits (untreated controls $3.9 \pm 0.7 \mathrm{mN} / \mathrm{mm}^{2}$, pair-fed controls $15.9 \pm 2.3 \mathrm{mN} / \mathrm{mm}^{2}$, infected group $4.9 \pm 0.6 \mathrm{mN} / \mathrm{mm}^{2}$ ).

Morphometry: Morphometric measurements were obtained to determine whether the increased contractility of the longitudinal muscle in undernourished animals and the decreased contractility of the longitudinal muscle in infected and control animals were due to a change in the number or the size of smooth muscle cells. Longitudinal smooth muscle cell hyper- or hypotrophy can occur in two dimensions - along the long axis and circumferentially. Hyper-or hypotrophy along the longitudinal axis must be associated with either a change in the circumference or a change in the thickness of the longitudinal smooth muscle coat. The number of cross-sectioned longitudinal smooth muscle cells per unit area indicates changes in the circumferential plane. If the significantly greater ability of longitudinal smooth muscle from the pair-fed animals to develop stress is attributable to a hypertrophy in length or circumference of the smooth muscle cells, there should be an increase in the circumference and/or the thickness of the longitudinal smooth muscle coat, or an increase in the number of crosssectioned longitudinal smooth muscle cells per unit area, respectively.

Ileal circumference was not different between the infected and the pair-fed animals $(3.5 \pm 0.2$ versus $3.3 \pm 0.3 \mathrm{~cm}$, respectively), and the proportionate thicknesses of the distal ileal longitudinal muscle layer in the muscularis propria were not significantly different among control, pair-fed and infected animals $(0.17 \% \pm 0.03 \%, \quad 0.14 \% \pm 0.02 \%$ and $0.13 \% \pm 0.02 \%$, respectively; $\mathrm{P}=0.57$ [not significant]). There was no significant difference in the number of cross- sectioned longitudinal smooth muscle cells per unit area among control $\left(22.8 \pm 3.2 \times 10^{3} / \mathrm{mm}^{2}\right)$, pair-fed $\left(26.3 \pm 5.0 \times 10^{3} / \mathrm{mm}^{2}\right)$ or infected $\left(29.1 \pm 6.1 \times 10^{3} / \mathrm{mm}^{2}\right)$ animals. These data suggest that no change in smooth muscle cell size developed in response to a short period (six days) of undernourishment alone (pair-fed group) or to infection with Y enterocolitica.

Immunoassay: For all immunoassays, the protein concentration of the sample or standard was directly proportional to optical density. The linear relationship was reproducible, and $\mathrm{r}$ values were consistently above 0.94 .

Due to the highly conserved nature of the amino acid sequences of the contractile proteins, the isoactin and myosin antibodies are reactive in several species, including
TABLE 1

Contractile protein levels in ileal longitudinal muscle measured six days after Yersinia enterocolitica infection

\begin{tabular}{lccc}
\hline $\begin{array}{l}\text { Contractile } \\
\text { protein }\end{array}$ & $\begin{array}{c}\text { Untreated } \\
\text { control }(\mathbf{n = 1 1})\end{array}$ & $\begin{array}{c}\text { Pair-fed control } \\
(\mathbf{n = 1 4 )}\end{array}$ & $\begin{array}{c}\text { Y enterocolitica- } \\
\text { infected } \\
(\mathbf{n = 1 6})\end{array}$ \\
\hline $\begin{array}{c}\text { Gamma-enteric } \\
\text { isoactin } \\
\% \text { total }\end{array}$ & $0.109 \pm 0.200$ & $0.128 \pm 0.024$ & $0.090 \pm 0.015$ \\
$\begin{array}{c}\text { protein } \\
\text { Alpha-vascular } \\
\text { isoactin }\end{array}$ & $0.053 \pm 0.012$ & $0.060 \pm 0.011$ & $0.052 \pm 0.010$ \\
$\begin{array}{c}\text { Total actin } \\
\text { Myosin heavy } \\
\text { chain }\end{array}$ & $0.107 \pm 0.005$ & $0.146 \pm 0.016$ & $0.127 \pm 0.015$ \\
\hline
\end{tabular}

Relative abundance values of gamma-enteric isoactin, alpha-vascular isoactin, total muscle actin and myosin heavy chain are reported as optical density readings. Relative abundance values of gamma-enteric isoactin are also expressed as percentage of total protein. The absolute abundance values were determined against a standard curve of chicken gizzard actin abundance

the rabbit (personal communication). The ability of each antibody to recognize preferentially specific isoactins $(23,24)$ or myosin heavy chain $(25,26)$ has been documented in the literature. To confirm the reported specificity of antibody reactivity, preliminary experiments were performed that demonstrated that the antibody to gamma-enteric isoactin, B4, was unable to recognize actin from rat abdominal aorta but did elicit a positive, proportional response to commercially prepared chicken gizzard actin. The antibody to alpha-vascular isoactin, $1 \mathrm{~A} 4$, responded positively and proportionally to rat aorta and to chicken gizzard actin, although its sensitivity towards the latter was about eightfold less than that of the $\mathrm{V}$-enteric antibody. Rat tissue samples for immunoassay were prepared as described in the Animals and Methods section.

The proportion of total protein attributable to gammaenteric isoactin, B4, in longitudinal ileal muscle was not altered by pair-feeding or $\mathrm{Y}$ enterocolitica infection (Table 1). Similarly, the levels of alpha-vascular isoactin, total actin and myosin were not affected by any of the treatments (Table 1).

\section{DISCUSSION}

Previous studies have shown that undernourishment or pair-feeding, matching the reduced food intake associated with $Y$ enterocolitica enteritis, results in an enhanced contractile response to the muscarinic agonist carbachol and to potassium chloride-induced membrane depolarization in ileal longitudinal smooth muscle (7). The mechanism is unknown; however it probably reflects receptorindependent changes in smooth muscle function because the response can be reproduced with potassium chloride depolarization (7). Potential explanations include alterations in the following: intracellular signalling pathways; excitation-contraction coupling, including transmembrane calcium flux and calcium sensitivity; tissue hypo- or hy- 
perplasia; or changes in the contractile protein content and isoform distribution. The present work focuses on the latter two possibilities and demonstrates that the increased contractility of pair-fed tissues is not the result of tissue hypo- or hyperplasia, or a change in the relative content or isoform distribution of contractile proteins.

The potential for dysfunction or disease to alter muscle tissue expression of the genes responsible for contractile protein synthesis, thereby altering muscle tissue contractility, has best been described in the cardiovascular literature. It is well established that in the early stages following pressure-induced overload and hypertrophy of cardiac muscle the tissue responds by turning off expression of certain 'adult' genes and reactivating expression of a set of 'fetal' genes (27). Reactivation of fetal genes includes expression of actin and myosin isoforms, and results in cardiac muscle contractility changes $(15,17,18,20-22)$. Within the gastrointestinal tract, bypass of the middle $70 \%$ of the small intestine is associated with thickening of the muscularis propria in the functional segment, and with a rapid, specific increase in the content and concentration of alpha-smooth muscle actin mRNA (8). At the protein level, the distribution of actin isoforms was altered in gallbladder smooth muscle taken from prairie dogs fed a high cholesterol diet (9). These changes coincided with a previously demonstrated reduction in gallbladder contractility following high cholesterol feeding $(10,11)$, raising the possibility of an association between altered contractility and isoactin protein distribution. In another animal model of Trichinella spiralis infection involving rats, thickening of the muscularis propria, and the histologic appearance of intestinal smooth muscle hypertrophy and hyperplasia were noted during the intestinal phase of infection (12). Contractility of the proximal intestinal longitudinal muscle in these animals increased (13), associated with an increase in both the expression of the mRNA that encodes alpha-smooth muscle actin and the content of actin protein (14). In contrast, no such association between altered contractility and changes in the content or concentration of contractile proteins can be made in the present $\mathrm{Y}$ enterocolitica model. Furthermore, the 'catabolic stress' of reduced caloric intake in the undernourished control group was not sufficient to perturb the normal distribution, and quantity of actin and myosin isoforms in ileal longitudinal smooth muscle (Table 1).

The present study demonstrates that the enhanced stress response of ileal longitudinal smooth muscle in undernourished rabbits did not occur because of hypo- or hyperplasia, or alterations in contractile protein content or isoform distribution. Additional studies are needed to determine whether the enhanced stress response of ileal longitudinal smooth muscle in undernourished rabbits and the depressed response in tissues from undernourishedinfected animals (7) can be attributed to alterations in intracellular signalling pathways or excitation-contraction coupling, including transmembrane calcium flux or calcium.

ACKNOWLEDGEMENTS: This work was supported through funding by the Medical Research Council of Canada, Grant MT. 10014. Dr Chin is the recipient of Alberta Heritage Foundation for Medical Research and Medical Research Council of Canada Studentship awards.

\section{REFERENCES}

1. Kohl S. Yersinia enterocolitica infections in children. Pediatr Clin North Am 1979;26:433-43.

2. Maki M, Vesikar T, Rantala I, Gronroos P. Yersiniosis in children. Arch Dis Child 1980;55:861-5.

3. Marks MI, Pai CH, Lafleur L, Lackman L, Hammerberg O. Yersinia enterocolitica gastroenteritis: a prospective study of clinical, bacteriologic and epidemiologic features. J Pediatr 1980;96:26-31.

4. Simmonds SD, Noble MA, Freeman HJ. Gastrointestinal features of culture-positive Yersinia enterocolitica infection. Gastroenterology 1987;92:112-7.

5. O'Loughlin EV, Humphreys G, Dunn I, et al. Clinical, morphological, and biochemical alterations in acute intestinal yersiniosis. Pediatr Res 1986;20:602-8.

6. Scott RB, Gall DG, Diamant SC. Intestinal motility during acute Yersinia enterocolitica enteritis in rabbits. Can J Physiol Pharmacol 1989;67:553-60.

7. Scott RB, Tan DT. Yersinia enterocolitica enteritis affects rabbit intestinal longitudinal smooth muscle function. Am J Physiol 1992;262:G278-84.

8. Lai M, Thomason DB, Weisbrodt NW. Effect of intestinal bypass on the expression of actin mRNA in ileal smooth muscle. Am J Physiol 1990;258:R39-43.

9. Li YF, Bowers RL, Haley-Russell D, Moody FG, Weisbrodt NW. Actin and myosin isoforms in gallbladder smooth muscle following cholesterol feeding in prairie dogs. Gastroenterology 1990;99:1460-6.

10. Fridhandler TM, Davison JS, Shaffer EA. Defective gallbladder contractility in the ground squirrel and prairie dog during the early stages of cholesterol gallstone formation. Gastroenterology 1983;85:830-6.

11. Li YF, Weisbrodt NW, Moody FG, Coelho JU, Gouma DJ. Calcium-induced contraction and contractile protein of gallbladder smooth muscle after high-cholesterol feeding of prairie dogs. Gastroenterology 1987;92:746-50.

12. Blennerhassett MG, Vignjevic P. Vermillion DL, Collins SM. Inflammation causes hyperplasia and hypertrophy in smooth muscle of rat small intestine. Am J Physiol 1992;262:G1041-6.

13. Vermillion DL, Collins SM. Increased responsiveness of jejunal longitudinal muscle in Trichinella infected rats. Am J Physiol 1988;254:G124-9.

14. Weisbrodt NW, Lai M, Bowers RL, Harari Y, Castro GA. Structural and molecular changes in intestinal smooth muscle 
induced by Trichinella spiralis infection. Am J Physiol 1994;266:G856-62.

15. Schwartz K, Carrier L, Lompre AM, Mercadier JJ, Boheler KR. Contractile proteins and sarcoplasmic reticulum calcium-ATPase gene expression in the hypertrophied and failing heart. Basic Res Cardiol 1992;87:285-90.

16. Izumo S, Lompre AM, Matsuoka R, et al. Myosin heavy chain messenger RNA and protein isoform transitions during cardiac hypertrophy. J Clin Invest 1987;79:970-7.

17. Lompre AM, Schwartz K, d'Albis A, Lacombe G, Van Thiem N, Swynghedauw B. Myosin isoenzyme redistribution in chronic heart overload. Nature 979;282:105-7.

18. Schiaffino S, Samuel JL, Sassoon D, et al. Nonsynchronous accumulation of $\alpha$-skeletal actin and $\beta$-myosin heavy chain mRNAs during early stages of pressure-overload-induced cardiac hypertrophy demonstrated by in situ hybridization. Circ Res 1989;64:937-48.

19. Clark WA, Rudnick SJ, Andersen LC, LaPres JJ. Myosin heavy chain synthesis is independently regulated in hypertrophy and atrophy of isolated adult cardiac myocytes. J Biol Chem 1994;269:25562-9.

20. Schwartz K, Boheler KR, de la Bastie D, Lompre AM, Mercadier JJ. Switches in cardiac muscle gene expression as a result of pressure and volume overload. Am J Physiol 1992;262:R364-9.

21. Schwartz K, Lecarpentier Y, Martin JL, Lompre AM, Merecadier JJ, Swynghedauw B. Myosin isoenzymic distribution correlates with speed of myocardial contraction. J Mol Cell Cardiol 1981;13:1071-5.

22. Alpert NR, Mulieri LA. Increased myothermal economy of isometric force generation in compensated cardiac hypertrophy induced by pulmonary artery constriction in the rabbit. A characterization of heat liberation in normal and hypertrophied right ventricular papillary muscles. Circ Res 1982;50:491-500.

23. Lessard JL. Two monoclonal antibodies to actin: one muscle selective and one generally reactive. Cell Motil Cytoskeleton $1988 ; 10: 349-62$.

24. Sawtell NM, Lessard JL. Cellular distribution of smooth muscle actins during mammalian embryogenesis: expression of the $\alpha$-vascular but not the $\gamma$-enteric isoform in differentiating striated myocytes. J Cell Biol 1989;109:2929-37.

25. Longtine JA, Pinkus GS, Fujiwara K, Corson JM. Immunohistochemical localization of smooth muscle myosin in normal human tissues. J Histochem Cytochem 1985;33:179-84. 


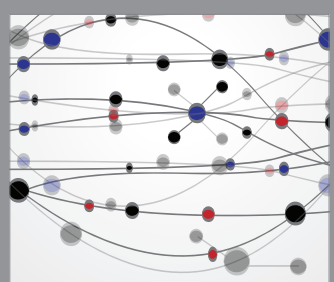

The Scientific World Journal
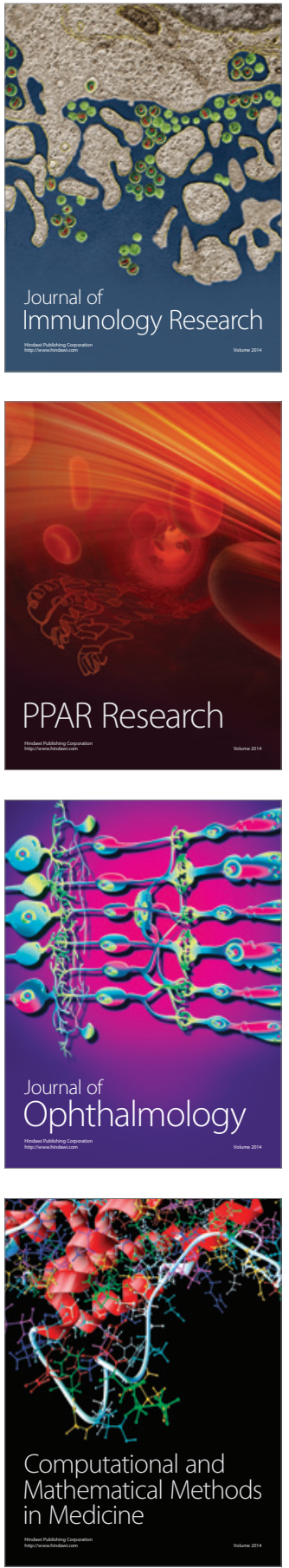

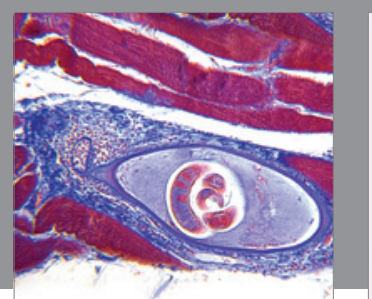

Gastroenterology Research and Practice

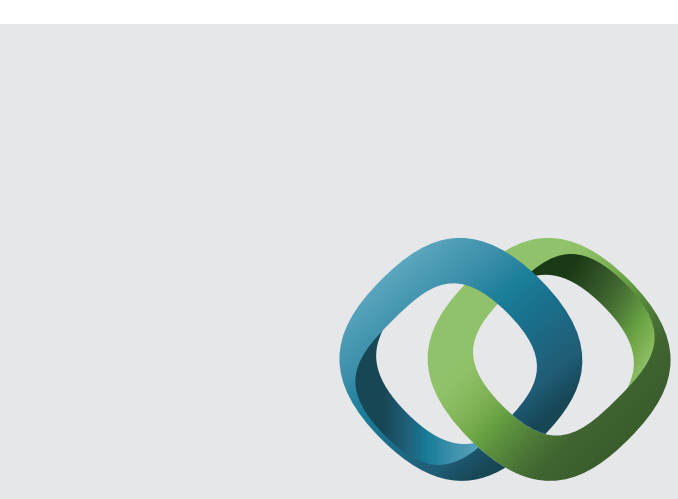

\section{Hindawi}

Submit your manuscripts at

http://www.hindawi.com
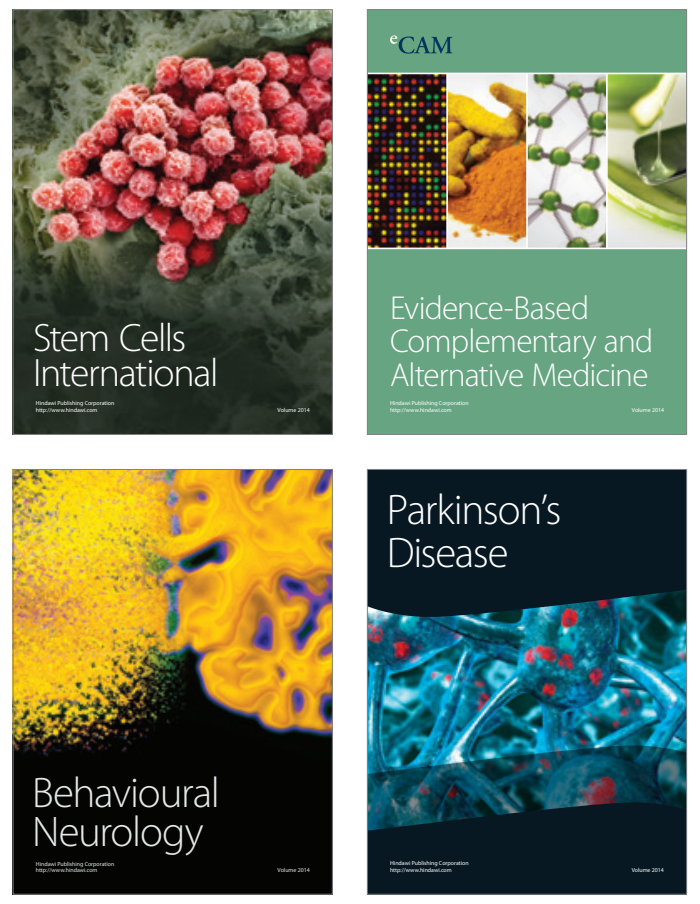
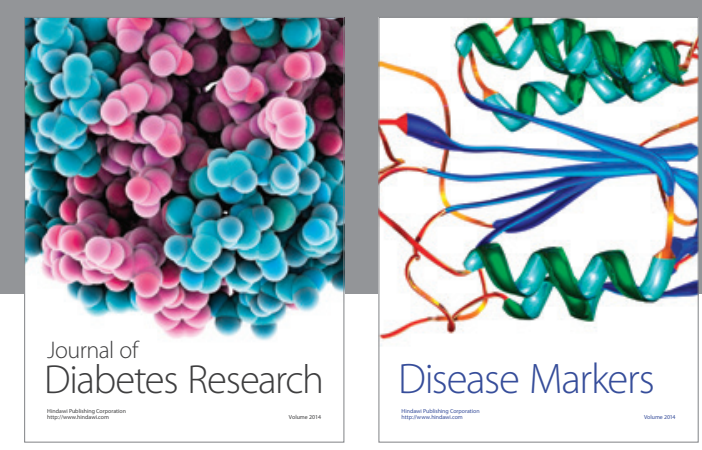

Disease Markers
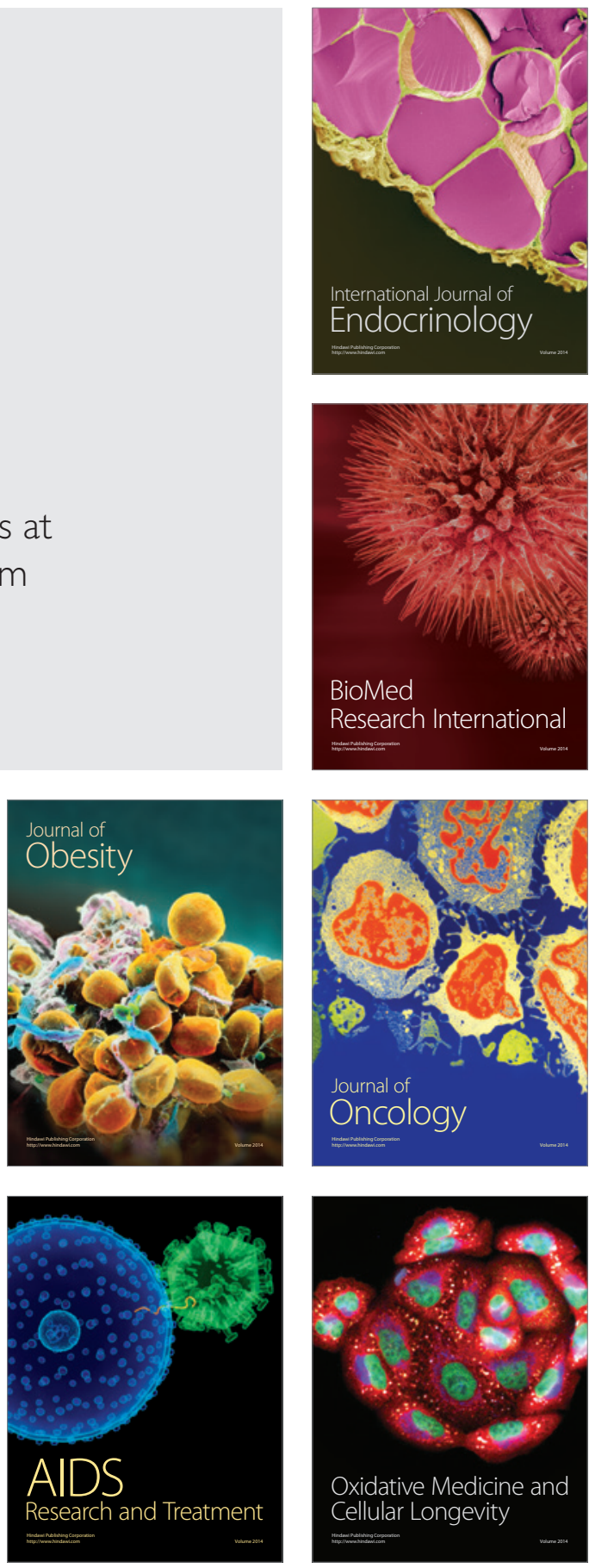